\title{
FROM FINANCIAL CRISIS TO FINANCIAL STABILITY (TURKISH EXPERIENCE)
}

\author{
Ali Arshadi* \\ ${ }^{*}$ Dr., Faculty Member of Monetary and Banking Research Institute (MBRI), IRAN.
}

\begin{abstract}
This paper try to give a picture of Turkish crisis during 2000-2001 and the reforms were fulfilled after that especially in financial system sector. Survey about experiences such as turkey can have many useful lessons for countries like Iran and other developing countries that have similar conditions.

Turkish experience show us in a unstable economic environment that has been characterized by runaway and chronic inflation ; high past through exchange rate; fragility in banking system and heavy fiscal dominance; could implement a structural reforms during a short period and come bake to the right way and reach to the amazing results as soon as possible. The conducted exit strategy in turkey consist of three main channel including 1) fiscal reforms; 2)adoption a sustainable monetary policy based on floating exchange rate and tightening monetary base and 3)finally banking sector restructuring. The consequence of conducted reforms can be shown in slowdown inflation rate and achievement to a stable economic growth.

It's necessary to be mentioned that turkey before 2001 reforms had experienced several efforts to achieve a suitable economic conditions but all of them had failed.

The structure of this paper is including: i) in the first section; the conditions before crisis that Turkish economy had be faced with them are drawn. ii) And in the second sector; the main performances were done to pass the crisis especially in the financial sector has been discussed. iii) Finally the lessons taken from Turkish will be explained.
\end{abstract}

Keywords: monetary policy; banking system; inflation targeting

\section{INTRODUCTION}

First of all, this point is interesting to know that prior to happening 2001 crisis in turkey; this country had done many efforts to reach stability but all of them failed. For example the stabilization policy based on crawling peg exchange rate that fallowed before 2000 failed and with the 2001 February crisis, Central Bank of Turkey (CBT) had no choice except letting Turkish lira to be float. ${ }^{3}$

\footnotetext{
${ }^{1}$ The best evidence for this comment can be shown with the trend of inflation during 2002-2004 periods. while in the November of 2000; inflation was 68 percent ;in the end of 2004 this index reached to the $14 \%$

The banking restructuring program was initiated in May 2001.

${ }^{3}$ Turkey signed an agreement with IMF that named standby program in 1999. The main core of the program was to tightening monetary policy and peg exchange rate system but there is a weakness in this program and that was not to pay attention enough to the fiscal laxity.
} 
Figure 1: The trend of Turkish lira depreciation (1990-2004)

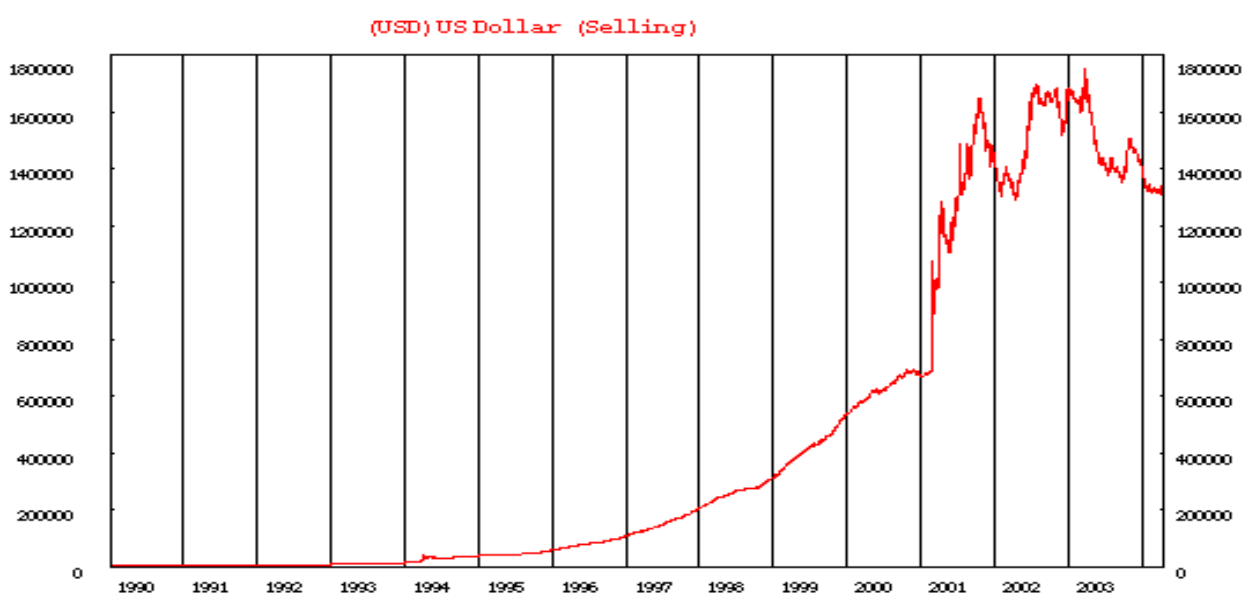

Source: CBRT

The main reason for these fails could be found in the structural challenges that Turkish economy were combating with them.in fact until Turkish authorities didn't want to solve their problems permanently; every effort to reach a sustainable and stable equilibrium would failed. Looking at the some economic indicators during 1990-2000 shows this country was moving in the crisis road.

Figure 2: CPI inflation and highest interest rate during 1998-2008

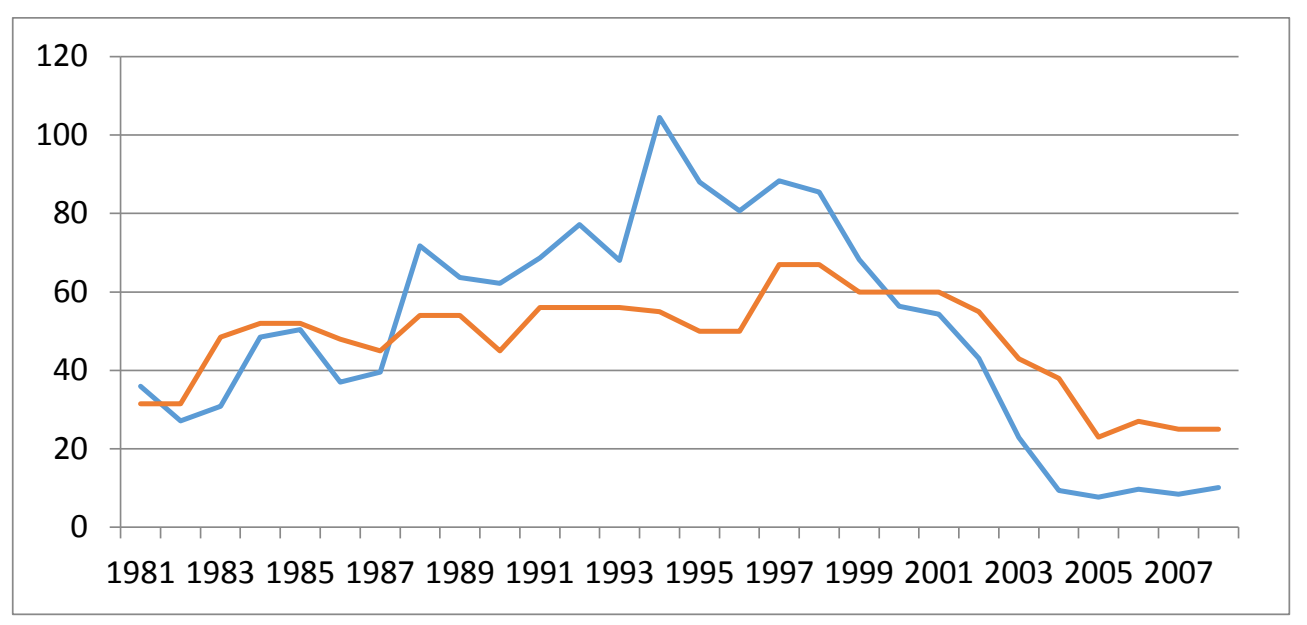

SOURCE: TURKISH STATISTICAL INSTITUTE

Figure 3: Turkish economic GDP growth (annual \%)

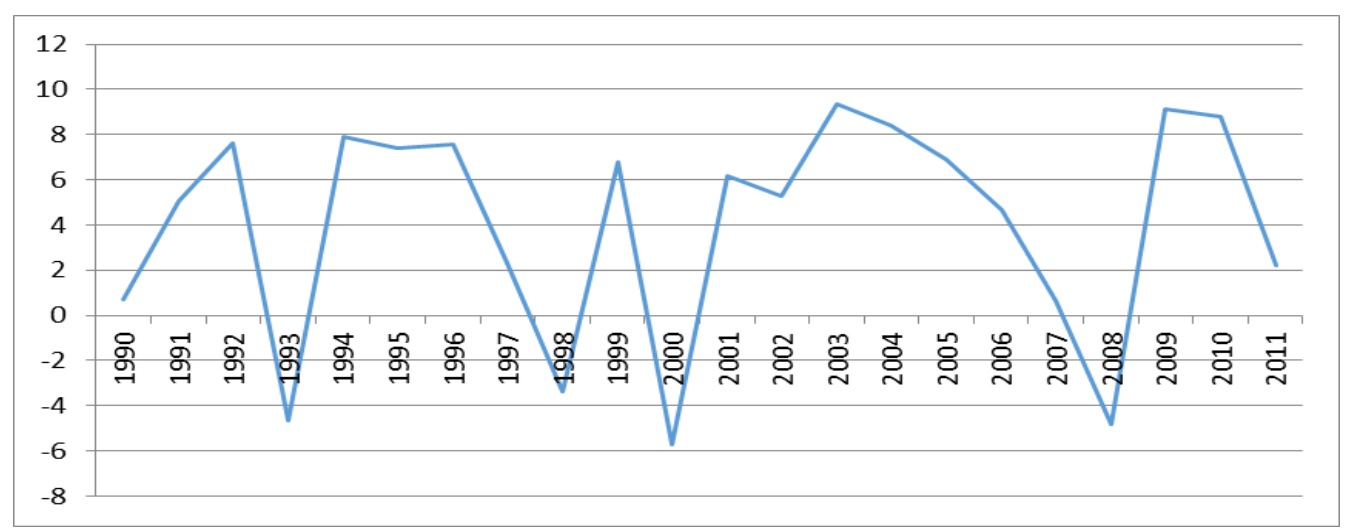

SOURCE: TURKISH STATISTICAL INSTITUTE

${ }^{4}$ During this period unstable economic growth accelerated the falling process into crisis. 
In these conditions (chronic high inflation; weak economic growth accommodated with volatility), Turkish economy needed to have some efficient reforms. For example in the scope of monetary policy; turkey decided as an alternative option and also with the experience the same countries like chili, inflation targeting regime was nominated as an ultimate choice.

To understand what caused to the 2001 crisis in Turkey, we need to consider the structural problems that Turkish Economy Faced with them during 1990-2000. Two of the most important challenges of turkey were:

- heavy fiscal dominance

- fragility in banking sector

\section{HEAVY FISCIAL DOMINANCE}

The net public depts. to GNP ratio in 2001 reached to 90.5 percent and more than half of the total government depts was either in Indexed form or denominated in foreign currency. In these conditions there was not enough room for active monetary policy. Also according to reinharts composite dollarization Index, Turkey was a highly dollarized economy.in the following charts can be observed the ratio of public sector borrowing requirement has been decreased after 2002 while domestic debt is experiencing an upward increase. In fact, the experience of turkey illustrate that attention to the diminishing of budget deficit is more important than the level of public debt.

Figure 4: the ratio of public sector borrowing requirement to GDP (1990-2006)

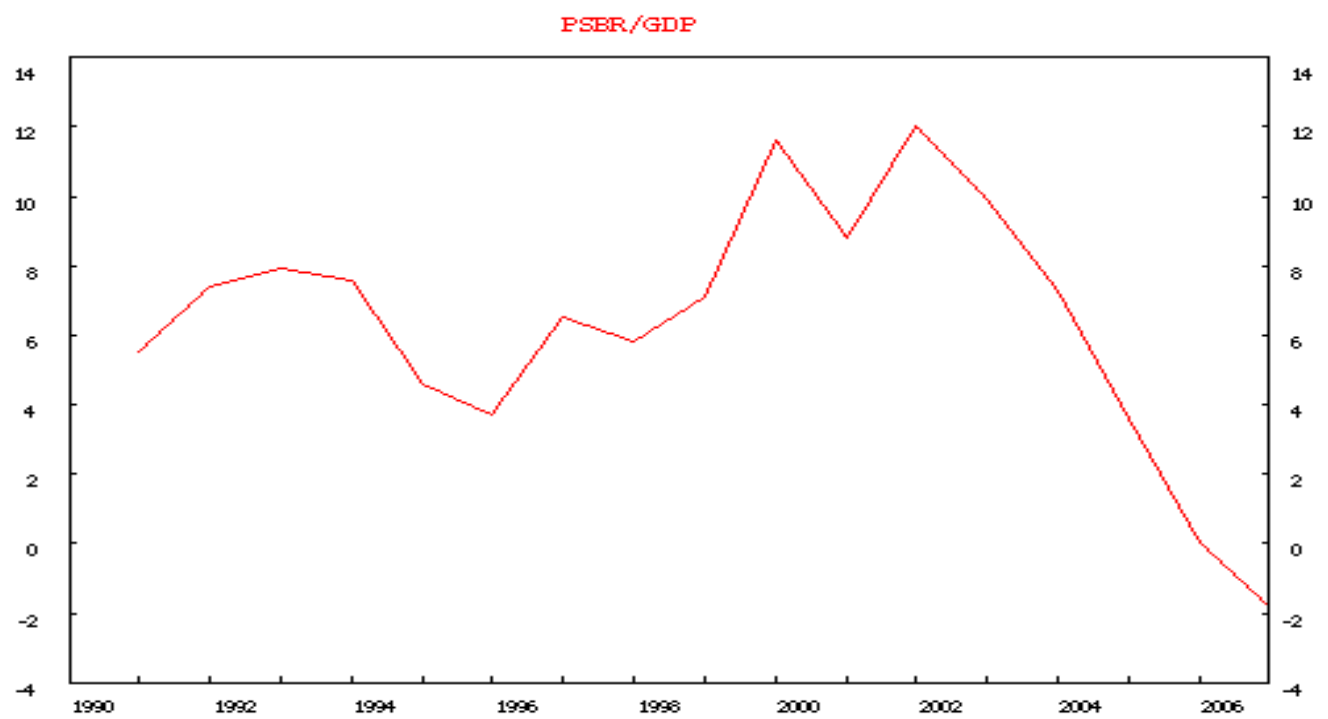

Figure 5: domestic debt (million us dollar)

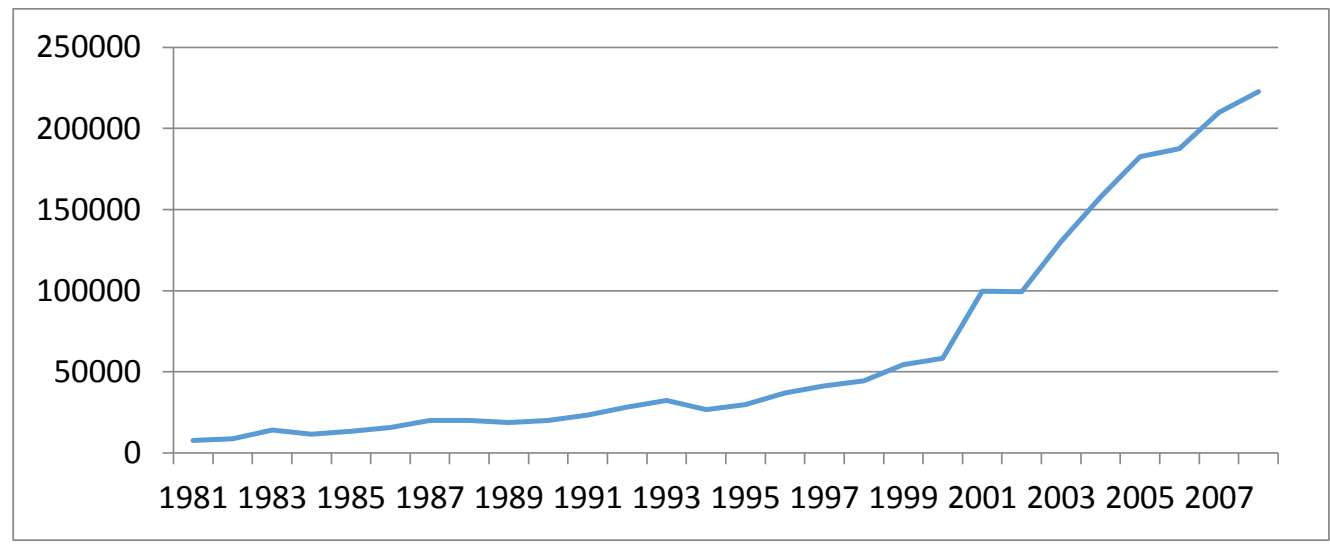

Source: SDIF

\footnotetext{
${ }^{5}$ If public debt continue to the upward slip then budget deficit probably will be face with problem
} 
The important issue about public debt related to the method of debt financing.in fact the main resource for financing was provided by banking system especially states banks and by purchasing issued government securities in high interest rates (bad assets accumulation was shaping). At the other hand; this kind of financing could create many problems for money market. In the following shape; it's shown the impact of fiscal dominance on the financial sector. ${ }^{6}$

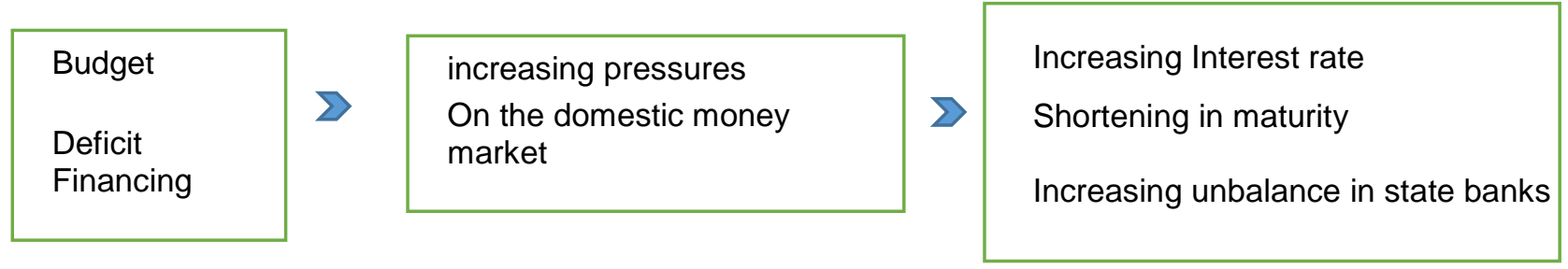

Figure 7: highest interest rate and its trend (1987-2001)

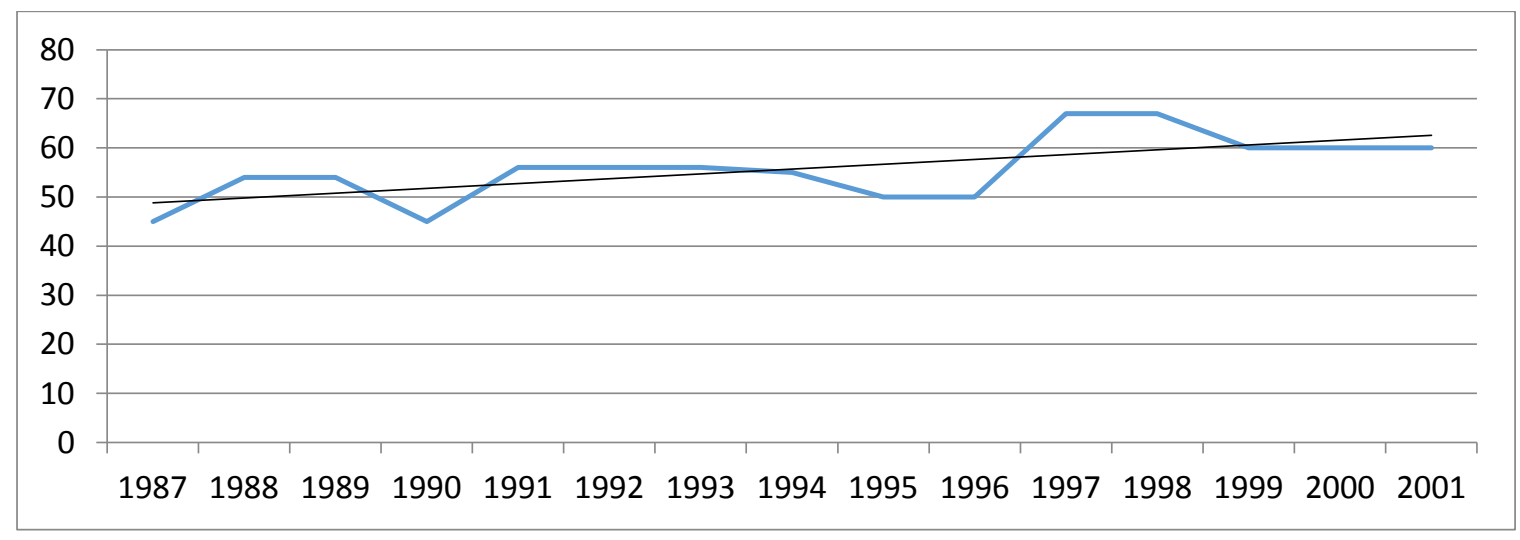

Source: Central bank of Turkey

Figure 8: weighted average of one year interest rate

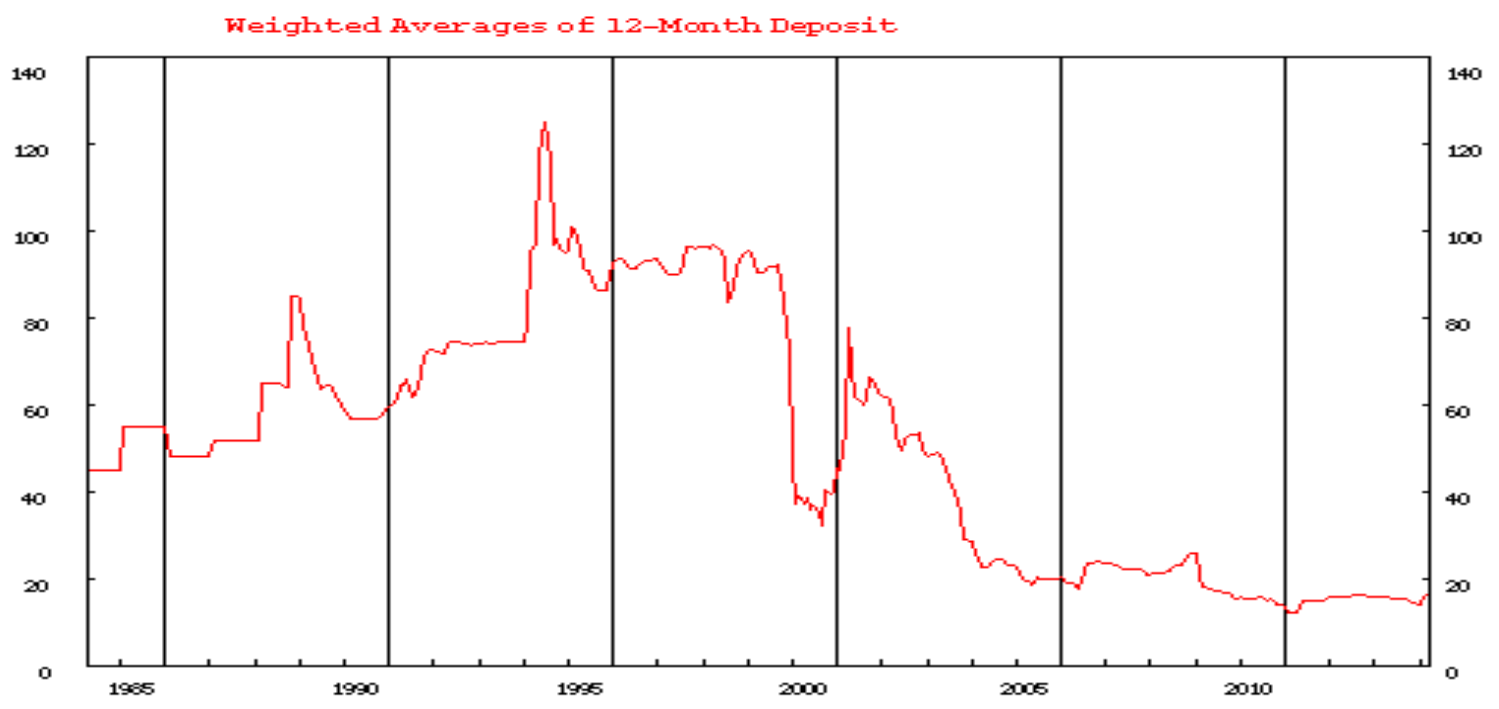

On the other hand; following Increasing interest rate in short run besides crawling peg exchange rate regime caused the capital inflow increase. Also with deteriorating of public dept., and tying Monetary expansion to

\footnotetext{
${ }^{6}$ The appended figure shows that dollarization had reached a peak during 2001 crisis just before adoption of Implicit Inflation Targeting.
} 
capital inflow, monetary base and liquidity experienced a massive growth in the end of 2001.

Figure 9: money and quasi money growth (annual \%)

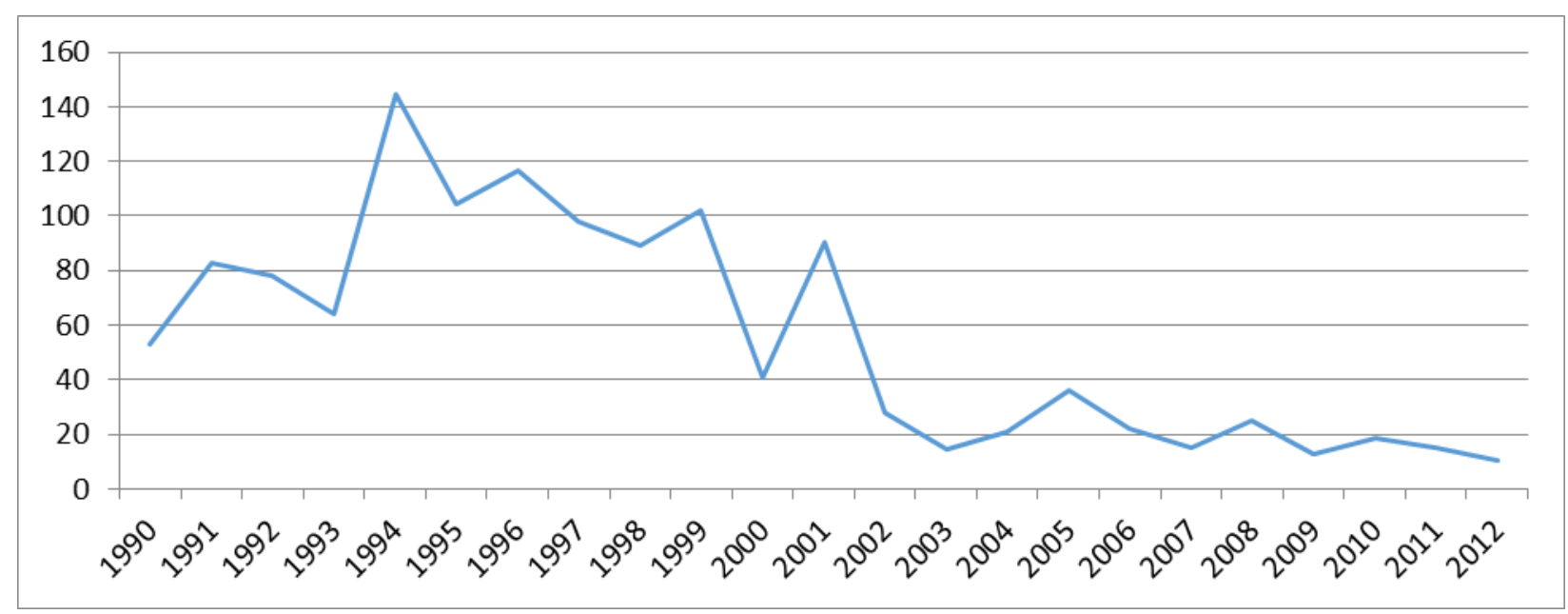

Source: Central bank of Turkey

Figure10: the trend of exchange rate after adoption floating system (us dollar against Turkish lira (20052014)

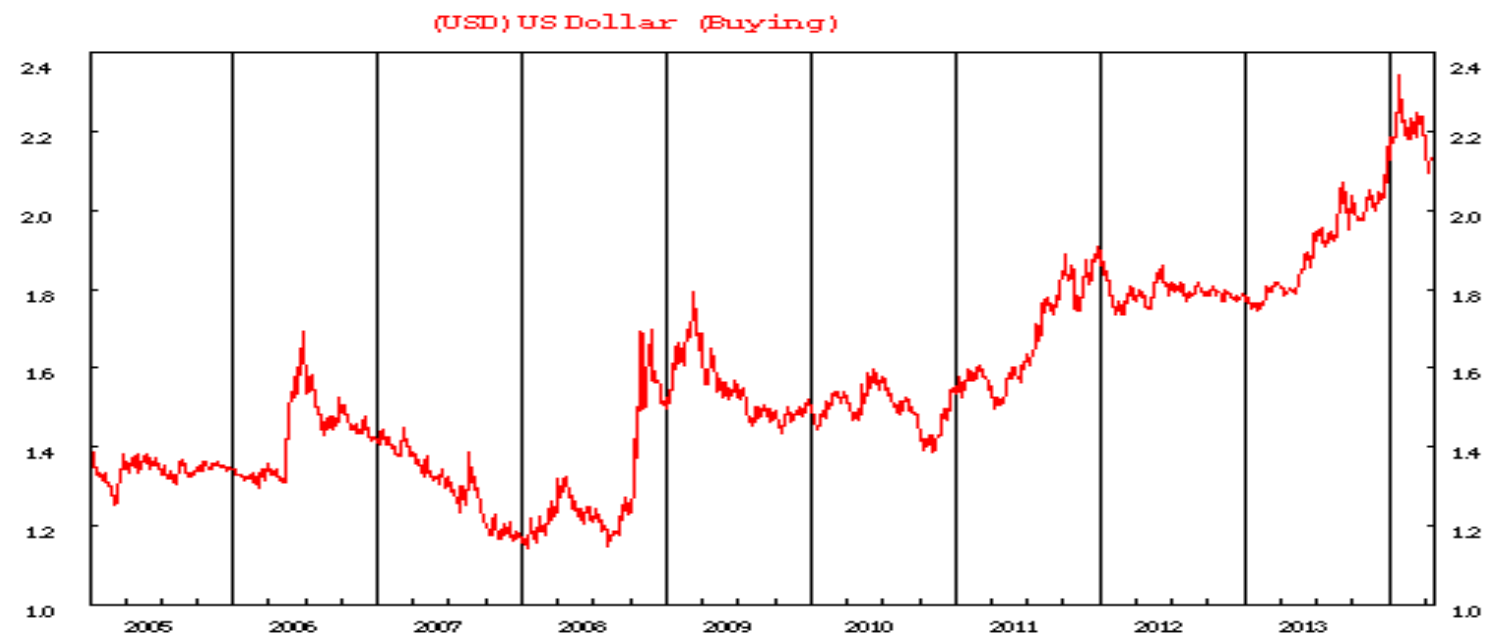

Source: Central bank of Turkey

Also due to weak growth rate of economy during 1990-2000, the instability of economy increased. Accordingly, the trend of inflation during 1990-2000 comparing with other periods experienced higher and too much volatile rates.

\section{FRAGILITY IN FINANCIAL SYSTEM}

Turkish banking sector had many problems. Some of them are own found adequacy; small scale and fragmented banking structure; weak asset quality; public banks which don't operate according to the market needs; weak supervision and inefficient internal control. Meanwhile; one of the most important challenges was this fact that the main mission of banking system was defined public sector financing Rather than real sector.

Take a look to the sector's indicators during 1995-2001 illustrate the challenges of banking system were faced with them. The ratio of non-performance loans to total loans started to increase in 1998 and reached to

${ }^{7}$ During 1990s, entrance into the sector was easy and revocation process was difficult. 
$11.9 \%$ percent in 2000. Also an open foreign exchange position was a structural feature of Turkish banking system. Look at the foreign asset to foreign liability ratio indicate banking system would experience a critical status because system vulnerability was increasing (table 1 ).

Table 1: commercial banking sector's indicators

\begin{tabular}{|c|c|c|c|c|c|c|}
\hline & $\mathbf{1 9 9 5}$ & $\mathbf{1 9 9 6}$ & $\mathbf{1 9 9 7}$ & $\mathbf{1 9 9 8}$ & $\mathbf{1 9 9 9}$ & $\mathbf{2 0 0 0}$ \\
\hline $\begin{array}{c}\text { Nonperformance } \\
\text { loans/total loan }\end{array}$ & 2.8 & 2.2 & 2.4 & 7.2 & 10.7 & 11.6 \\
\hline $\begin{array}{c}\text { Foreign asset/ } \\
\text { foreign liability }\end{array}$ & 90.6 & 93.6 & 89.6 & 84.9 & 79.4 & 75.9 \\
\hline $\begin{array}{c}\text { Liquid foreign asset/ } \\
\text { foreign liability }\end{array}$ & 44.8 & 44.6 & 41 & 39.5 & 40 & 35.9 \\
\hline $\begin{array}{c}\text { Asset/liability(with 3 } \\
\text { months or shorter } \\
\text { maturity) }\end{array}$ & - & - & 45.8 & 45.7 & 46.3 & 39.9 \\
\hline
\end{tabular}

Source: central bank of turkey

Meanwhile the statue of private banks and public banks was different. On the asset side; increasing size of duty loss of public banks and their need to finance by short term credits was a main challenge. On the liability side, the ratio of lira to foreign exchange liability shows a major difference between the two groups. The ratio was lower and decreasing for private banks while public banks were more open to interest risk.

Because of insufficient budget sources, for example duty less receivables has exceeded \%50 in ziraat bank and \%65 in halk bank. Public Banks have covered their liquidity needs from money market with short term at high cost. This statue augmented instability of the financial sector.

Figure12: development of banking sector's fundamental indicators
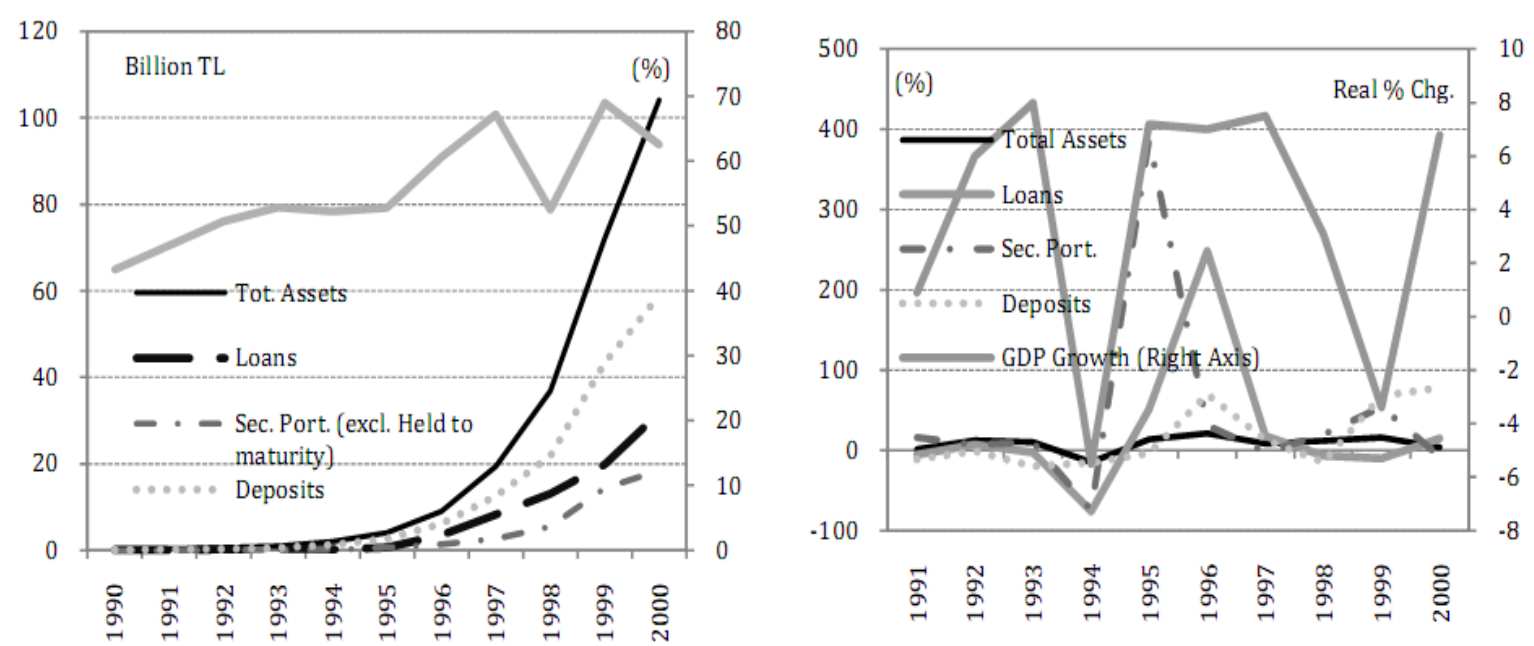

In fact, the securities and governments bounds had an interest share in the banking balance sheet. Another reflection for banking sector receding from its fundamental functions is observed from its income expenditure structure. The most remarking point during 1990-2000 is that the share of interest income from credits within total interest incomes has continuously decreased from $\% 60$ to $\% 38$.

In fact, the securities and governments bounds had an interest share in the banking balance sheet. Another reflection for banking sector receding from its fundamental functions is observed from its income expenditure structure. The most remarking point during 1990-2000 is that the share of interest income from credits within total interest incomes has continuously decreased from $\% 60$ to \%38(table2). During this period, the share of credits within total assets in banking sector which was \%47 in 1990 has decreased to \%33 in

${ }^{8}$ While in 1990, sector's total asset was TL 170.3 million, loans were TL80 million and deposits were TL 95.3 million. This size increased respectively to 104.1 billion, TL 31.8 billion and 58.9 billion in 2000 
$2000{ }^{9}$

Table2: Some of the fundamental income indicators

\begin{tabular}{|l|c|c|c|c|c|c|c|c|c|c|c|}
\hline & 1990 & 1991 & 1992 & 1993 & 1994 & 1995 & 1996 & 1997 & 1998 & $\mathbf{1 9 9 9}$ & $\mathbf{2 0 0 0}$ \\
\hline $\begin{array}{l}\text { INTREST } \\
\text { INCOME/TOTAL } \\
\text { INCOM }\end{array}$ & 74.7 & 71.6 & 76.1 & 73.3 & 58.7 & 66.9 & 67.9 & 68.7 & 69.1 & 58.1 & 51.5 \\
\hline $\begin{array}{l}\text { Net interest } \\
\text { income/total } \\
\text { assets }\end{array}$ & 5.2 & 7 & 6.8 & 8.2 & 8.8 & 6.3 & 7.6 & 7.7 & 9.4 & 6.6 & 4.3 \\
\hline $\begin{array}{l}\text { Interest taken } \\
\text { from credits/total } \\
\text { interest income }\end{array}$ & 69.2 & 67.4 & 64 & 63.7 & 61.7 & 62.8 & 60.6 & 61.3 & 46.6 & 37.2 & 38 \\
\hline $\begin{array}{l}\text { Interest taken } \\
\text { from } \\
\text { securities/total } \\
\text { interest income }\end{array}$ & 20.4 & 21.1 & 23.1 & 25.6 & 23 & 23.9 & 24.5 & 21.9 & 22.2 & 24.7 & 19.4 \\
\hline $\begin{array}{l}\text { Credit interest } \\
\text { income/total } \\
\text { income }\end{array}$ & 31.8 & 21.3 & 26.1 & 20.2 & 8.7 & 15 & 12.5 & 12.2 & 11.3 & 7.4 & 7.9 \\
\hline
\end{tabular}

Source: BRSA

Figure13: share of deposit and SP within assets and share of SP within internal debt stock
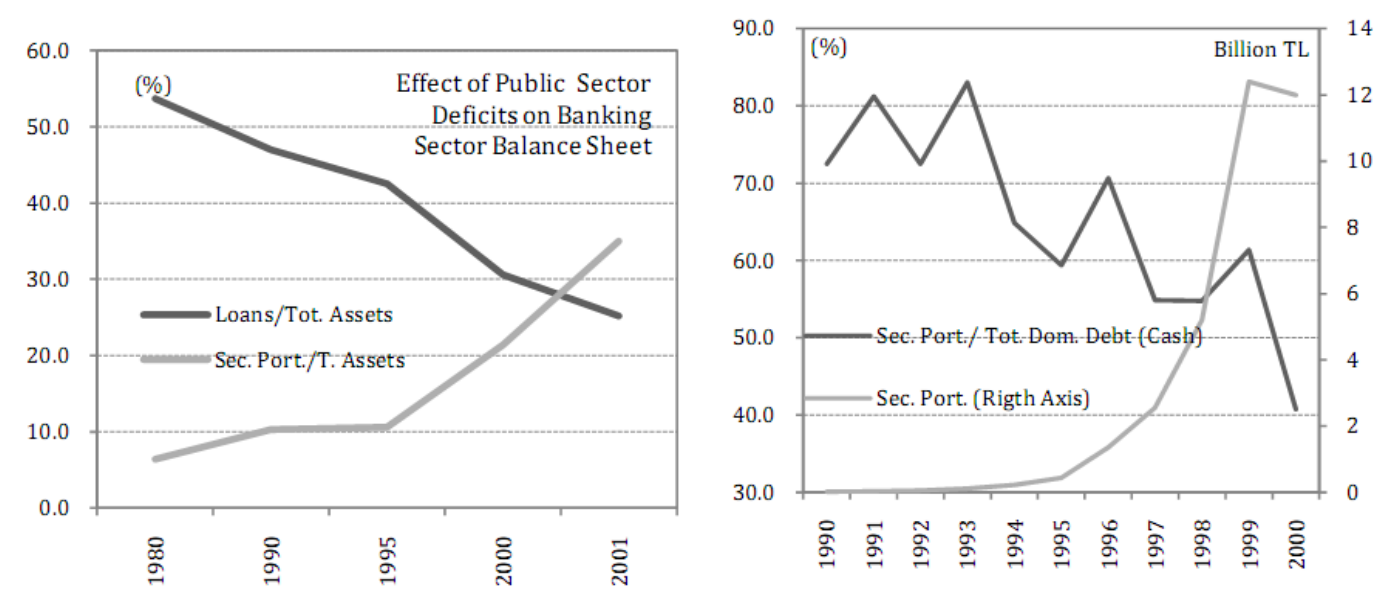

Source: BRSA, BAT

\section{FORMATION OF FINANCIAL CRISIS}

In the November 2000; several events happened:

- Interest rate increased significantly

- BTR bank experienced bankruptcy and help to tension expansion in financial market

- Stock exchange market was faced with a collapse

- Central bank reserve decreased rapidly

Due to increasing tension in the financial market; demand for foreign exchange increased and central bank started to sell its reserve. This issue caused to increasing pressures on the money market and more deteriorating unbalance problem for banking system especially in state banks.

\footnotetext{
${ }^{9}$ Similarly the credit /deposit ratio which was \%84 in 1990 reached to \%51 in 2000.
} 


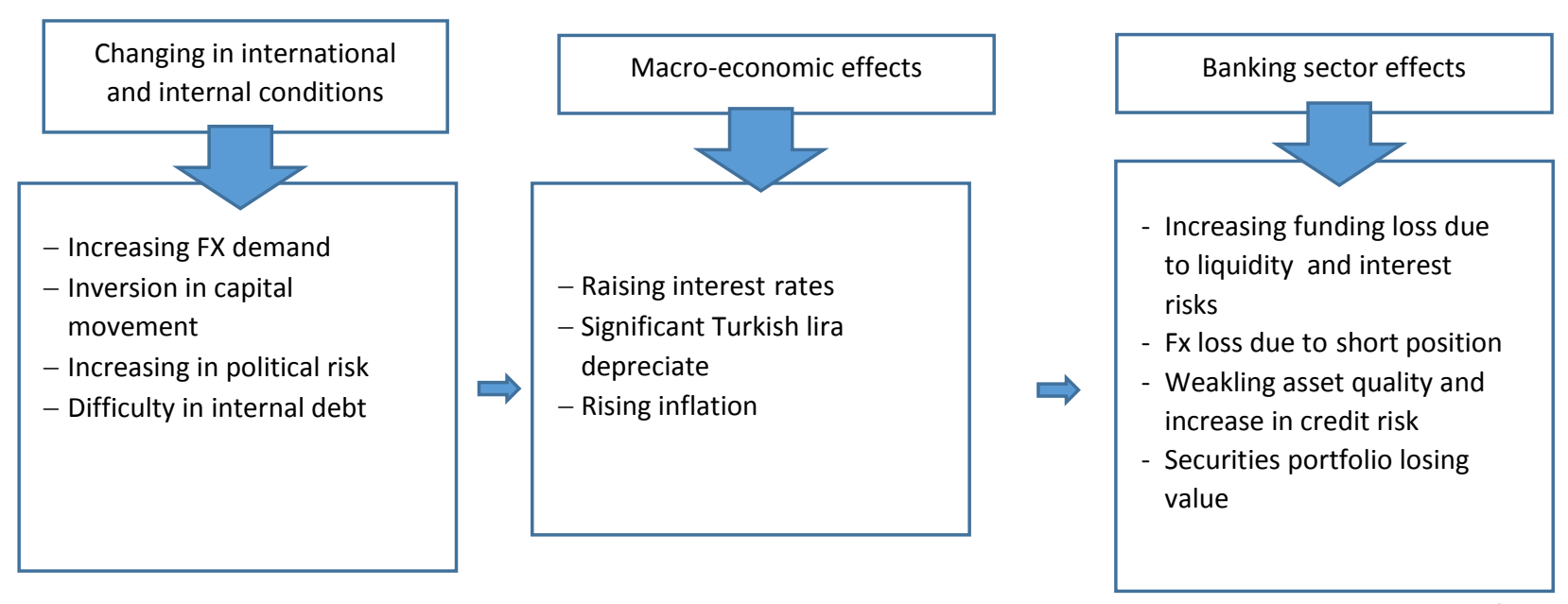

In this period; a sharp slowdown in real economic activity was shown. Also Following the collapse of the crawling peg; Turkish lira depreciated massively and annual Inflation rate rose to 68 percent at the end 2001.

Figure14: industrial production and number of firms established and closed
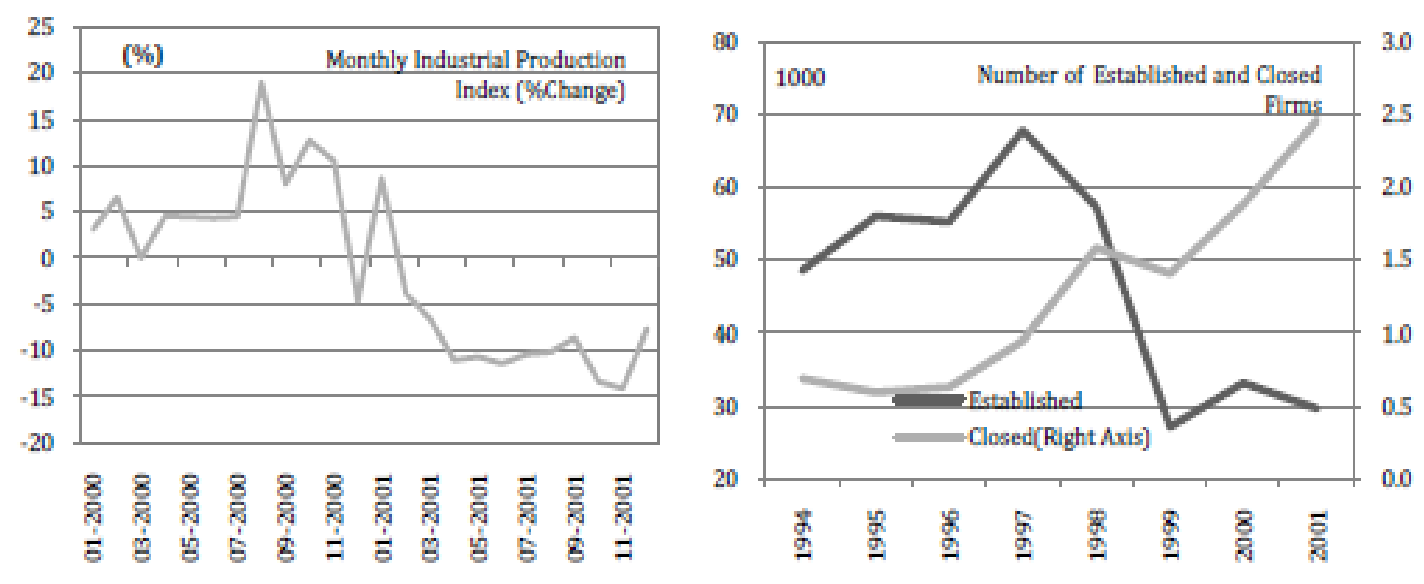

Source: TurkStat.

Shrinking economic activity in 2001 caused the deposit stream into banking sector start to be decreased and also the structure of deposit switched to the short run and to be held as foreign exchange instead of Turkish lira.

Figure15: deposit banks loan-deposit volume and CBRT balance sheet indicators 

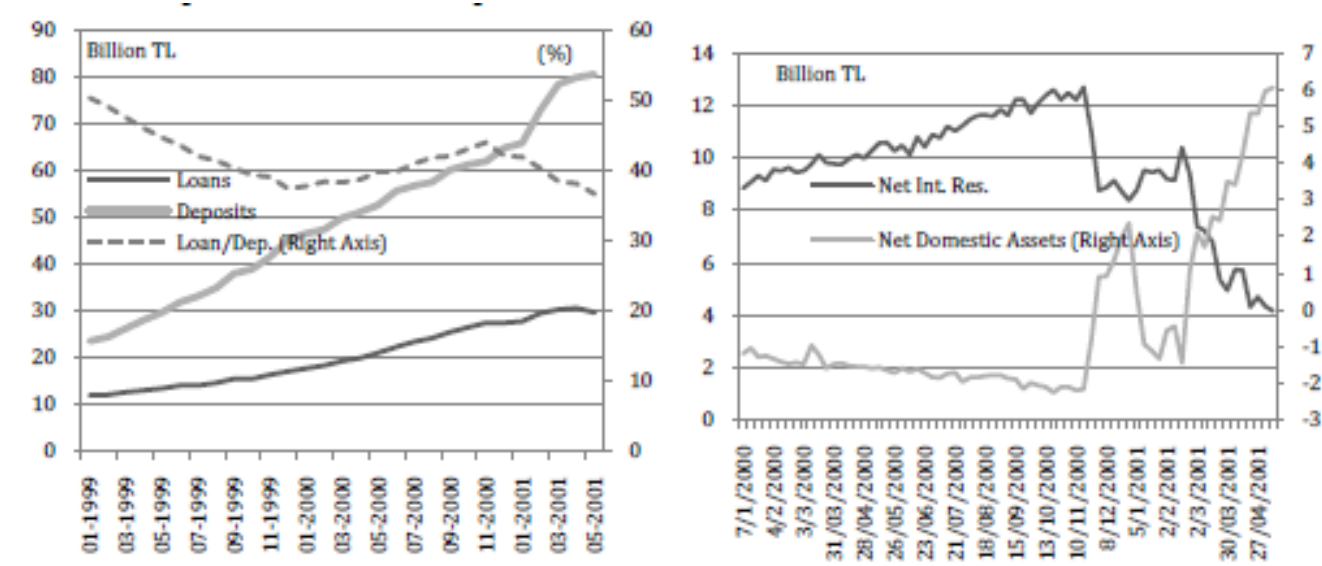

Source: BRSA, CBRT

It's necessary to say in the starting crisis, central bank thought by lessening put limitation on the net domestic asset could prevent the tension development in the money market but even injected liquidity to market couldn't diminish the overnight interest rates and from other side conducted measures by central bank resulted to increasing pressure on central bank reserve.

\section{REFORMS CONDUCTED AFTER CRISIS}

Totally in order to have a sustainable performance in the economic environment; turkey's authorities decided to do some reforms in two categories:

- Macro structural reforms(fiscal sector and central bank)

- Restructuring the financial sector( central bank \& banking system)

About former item; two groups of reforms were done; first in fiscal policy and second in monetary policy. In the fiscal policy; the program was determined to reach a $6.5 \%$ surplus in 2002.in fact the fundamental aim of the reform after 2001 is to providing the financial discipline.

Figure16: the ratio of public sector borrowing requirement to GDP
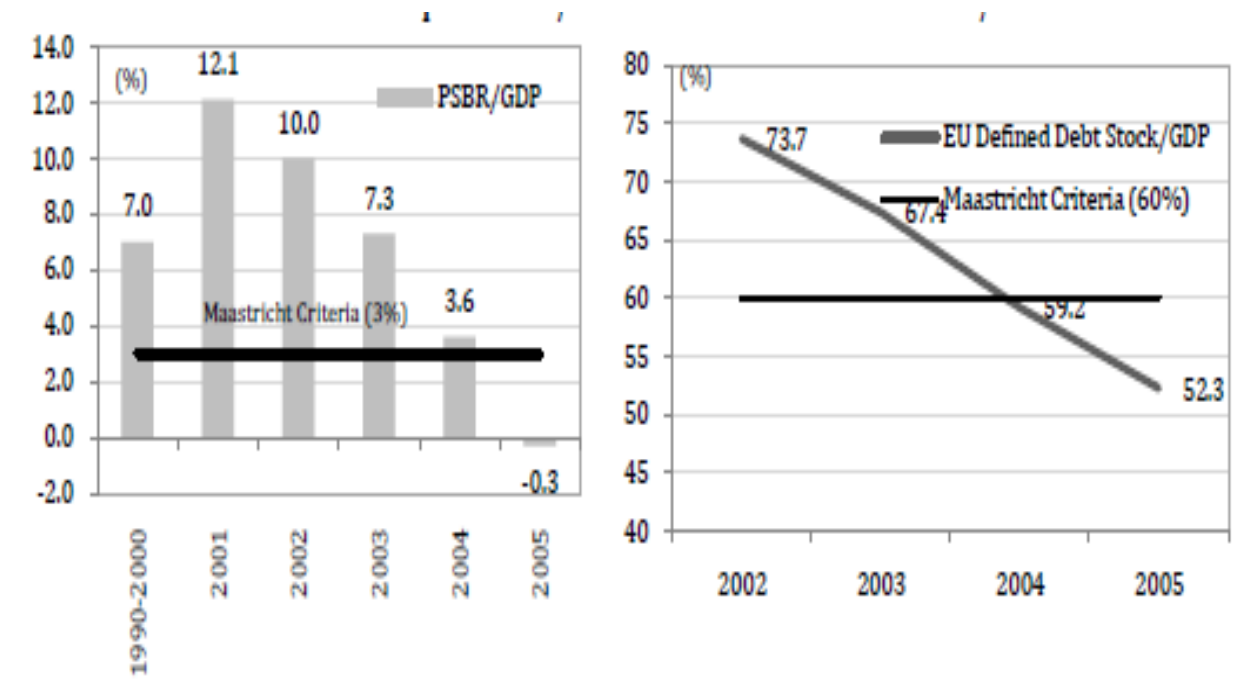

Source: Treasury

But about monetary policy; one of the main implemented reforms was amending central bank law. On the base of new law; central bank was prohibited to give and extend loans to the treasury and public sector institutions. Also with movement toward floating exchange rate system; monetary policy focused on price 
stability. In fact while short term interest rates were used as fundamental instrument of monetary policy; a monetary base size consist with inflation targeting took over as a nominal anchor function. Also implicit inflation targeting was applied within the period of 2002-2005.central bank reduced its intermediation in money market and foreign exchange market in interbank money market.

In addition; fixed exchange rate was substituted with floating exchange rate and also central bank announced its target as full-fledged inflation targeting after 2006.usally tow instruments were applied for this new monetary policy framework including: interest rate corridor and required reserves.in fact the main instrument of central bank for managing money market was one - week REPO auctions. It's necessary to say the corridor lie between the rate of central bank and overnight money market. Also if a bank need to liquidity; central bank provide it short term fund.

But about restructuring of financial sector; the banking reforms program announced on May 2001 that focused on returning banking to the intermediation function and expanding competitiveness. This program was defined in four blocks:

- Restructuring public banks financially and operationally

- Prompt resolution of banks by SDIF

- Bringing healthy structure to banks which were affected negatively from the crisis

- Improvement supervision

\section{OPERATIONAL RESTRUCTURING PUBLIC BANKS}

This program was aimed to improve restructuring technology; products; loans; financial control; planning; risk management and service structure of these banks. Some of the most important steps are:

- The duty losses which reached to usd 17.5 billion at the end of 2001 were liquidated. This practice was done by issuing special governments bounds.

- In order to reduce short term liquidity of public banks to private banks and non-bank sector; they should meet their liquidity requirements by repo or direct sales from central bank. The undersecretariation of the treasury contributed to the development of cash inflow and led to reduction in pressures of public banks on short term interest rates.

- On the base of new law; the statues of ziraat bank and halk bank was converted to the corporation and management of these two transferred to a joint executive board.

- License of emlak bank revoked and this bank transferred to ziraat bank.

-With the resolution of banking regulation and supervision agency; the operational license of banks in trouble were cancelled and their partnership rights and their management transferred to the SDIF. ${ }^{10}$

- The short termed liability to central bank (for the transferred banks to SDIF) was zeroed.

- The foreign exchange position of banks under SDIF decreased by injecting indexed government securities.

- To strengthen and empowering private banks; two instrument were developed which are:(1)increasing main and supplementary capital( 2)establishment of asset management companies to resolve the nonperformance loans.

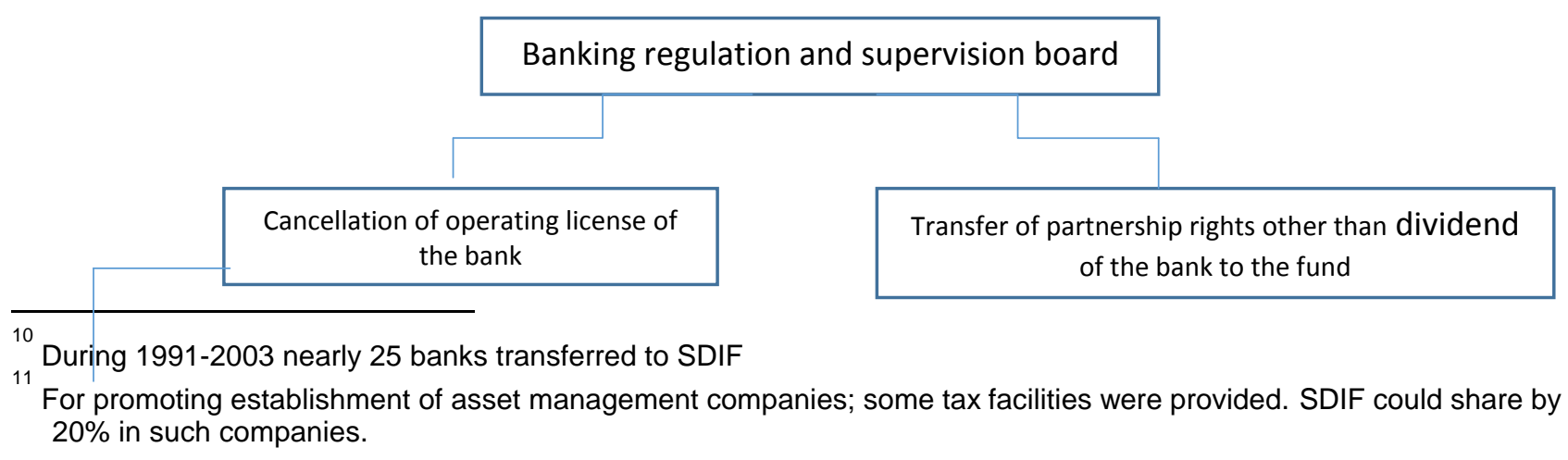




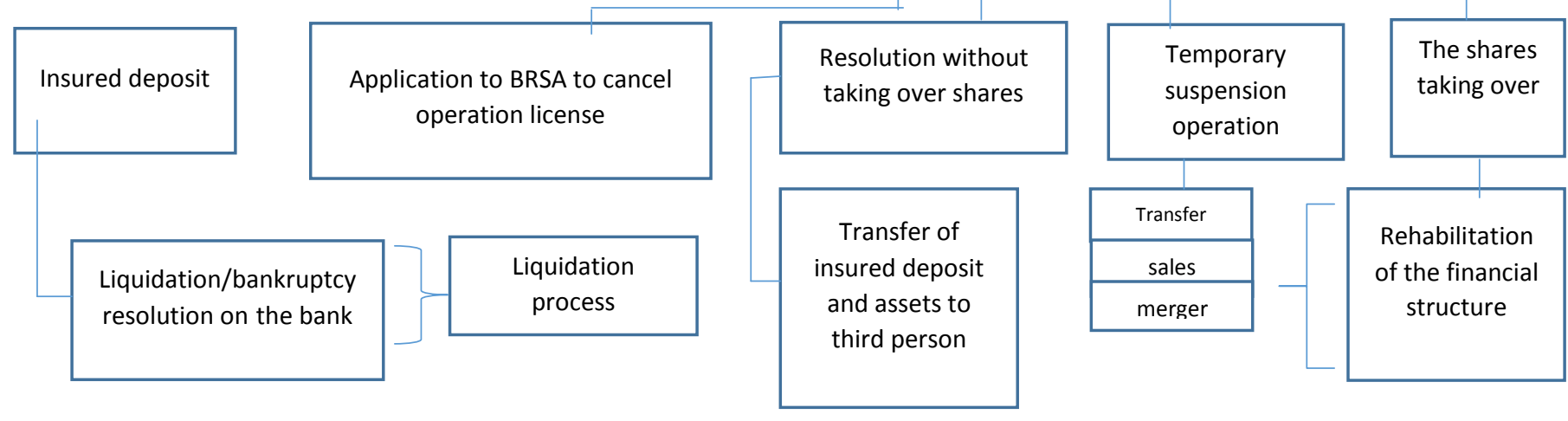

Following conducted measures, financial soundness indicators started to be better. Some of the improvements are illustrated in table3.

TABLE 3: BANKING SECTOE SOUNDNESS INDICATORS

\begin{tabular}{|l|c|c|c|}
\hline \multicolumn{1}{|c|}{ TITEL } & $\mathbf{2 0 0 1}$ & $\mathbf{2 0 0 5}$ & $\mathbf{2 0 0 6}$ \\
\hline Capital adequacy ratio & 3.4 & 21.6 & 20 \\
\hline Tier I capital/risk weighted assets & 4.5 & 22.4 & 19.3 \\
\hline NPL/gross loan & 11.2 & 4.9 & 3.8 \\
\hline FX net position/own funds & 23 & -.5 & 0.5 \\
\hline $\begin{array}{l}\text { Assets/liabilities with a maturity } \\
\text { up to 3 months }\end{array}$ & 10.5 & 47.9 & 46.4 \\
\hline Consumer loans/total loans & 5 & 31.8 & 34.3 \\
\hline $\begin{array}{l}\text { Net interest income/total gross } \\
\text { income }\end{array}$ & 8.5 & 30.1 & 26.3 \\
\hline ROA(AFTER TAX) & 0.1 & 1.5 & 2.4 \\
\hline ROE(AFTER TAX) & 1.5 & 10.4 & 20 \\
\hline
\end{tabular}

SOURCE: SDIF

\section{CONCLUSION}

Turkish experience indicates that initial conditions don't matter to be successful and reach to a sound economy. Also adverse conditions provide an opportunity to implementation reforms in economic environment. Some of the most important taken lessons from Turkish experience are:

- If a government able to control its deficit then the level of debt is not very important.in fact the main resource for disequilibrium stem from budget deficit not public debt.

- Turkish experience suggests that for countries with insufficient institutional development and limited operational capacity due to factors such as financial dominance; fragility in financial sector is better to start with a light regime. Central bank should stress that the responsibility of price stability cannot be only a job of single institution and it need the corporation and coordination of all institutes especially in fiscal sector.in fact without improvement in fiscal sector; central bank and financial sector will be faced with disequilibria in their balance sheet and in this state; standard monetary policy instruments can't work as well. 
- The conducted reforms in turkey have followed three main Channels. First; provide fiscal discipline as a main resource of instability. Second; restructuring banking system including strengthening capital structure; liquidating short term liability and duty loss; the resolution of the banks transferred to SDIF through the methods of merge; sale or direct liquidation; make transparency in private banks balance sheet by applying inflation accounting; accelerating to the settlement of bad assets and closing foreign currency open position specially in private banks and third; implementing new framework for monetary policy including switching from peg exchange rate system to float and anchoring monetary base in a inflation targeting regime.

- The main aim for central bank was determined to provide price stability and for this purpose a monetary policy applied including the implementation floating exchange rate and targeting monetary base consistent with inflation target and predicted economic growth. Also the targets for international reserve and domestic assets were determined.

- If central bank make anchor its balance sheet then can reach to a low inflation rate.

- Switching to the floating exchange rate in conditions that an economy meets high inflow steam of capital is very important to providing crisis.

- An important point about monetary variables behavior in Turkish experience has been indicated in appended figure. While the ratio of money to GDP after 2004 is bigger than that in 2001 and before that; the inflation rate trend in comparing two periods is exactly invers.

--strengthening efficient supervision in banking system and sector's soundness indicators monitoring and also having clear resolution process are necessary and precondition to achievement to a sound financial sector.

- Ultimately; successful in implementing structural reforms need serious support of authorities; otherwise any effort with discretionary approach to solve structural challenges would be fail.

\section{REFERNCE LIST}

Akinik'o and b.usta(2005)indicators for the dollarization process in turkey, working paper no.05/17,central bank of turkey, Ankara

CBT(2005): general framework of inflation targeting regime and monetary and exchange rate policy for 2006,www.tcmb.gov.tr

Kara ,h.(2006): Turkish experience with implicit inflation targeting; working paper no.06/03,central bank of turkey

Kara;h. (2008) exchange rate passes through in turkey. Working paper no, 05/04, central bank of turkey, Ankara.

Ozatay; f and g.sak (2007): banking sector fragility turkey's 2000-2001 financial crises 'Washington d.c brooking institution press'pp/121-160

World Bank (2006): turkey: country economic memorandum; toward macroeconomic stability and sustained growth; World Bank report no26301-tu Washington d.c.

www.tcmb.gov,

$\underline{\text { www.tmsf.gov }}$ 